\title{
Anterior Tarsal Tunnel Syndrome Secondary to Missed Talus Fracture: A Case Report
}

\author{
Atlanmı̧ Talus Fraktürüne İkincil Anterior Tarsal Tünel Sendromu: \\ Olgu Sunumu
}

\author{
Ahmet CETINKAL ${ }^{1}$, Kivanc TOPUZ ${ }^{2}$, Serdar KAYA ${ }^{3}$, Ahmet COLAK ${ }^{2}$, Mehmet Nusret DEMIRCAN² \\ ${ }^{1}$ Kasimpasa Military Hospital, Department of Neurosurgery, Beyoglu / Istanbul, Turkey \\ ${ }^{2}$ GATA Haydarpasa Training Hospital, Department of Neurosurgery, Uskudar/Istanbul, Turkey \\ ${ }^{3}$ GATA Training Hospital, Department of Neurosurgery, Etlik / Ankara, Turkey
}

Correspondence address: Ahmet CETINKAL / E-mail: acetinkal@yahoo.com

\begin{abstract}
The anterior tarsal tunnel syndrome (ATTS) has first been described by Kopell and Thompson in 1963. The anterior tarsal tunnel is formed by the fascia lining the inferior extensor retinaculum and talus as well as the navicular bone. Many ATTS cases with various etiologies have been reported since the first description. We report here an ATSS case resulting from a fibro-osseous structure that occurred after a missed talus fracture. The ATTS diagnosis can be made with a comprehensive clinical neurological examination and electrophysiological study. The treatment is based on the underlying etiology, while surgery is the most common treatment providing successful outcomes in the long term. KEYWORDS: Anterior tarsal tunnel syndrome, Nerve entrapment, Talus
\end{abstract}

öz

Anterior tarsal tünel sendromu (ATTS) ilk kez 1963 yılında Kopell ve Thompson tarafından tanımlandı. Anterior tarsal tünel, inferior ekstensör retinakulum ve talus ile naviküler kemik üzerini kaplayan fascia tarafından oluşturulur. İlk tanımlamadan itibaren bugüne kadar çeşitli etiyolojide ATTS olguları bildirilmiştir. Burada atlanmış talus kırığı sonrasında gelişmiş fibro-osseöz yapı sonucu oluşmuş bir ATTS olgusunu sunuyoruz. Detaylı bir klinik nörolojik muayene ve elektrofizyolojik inceleme ile ATTS tanısı kolayca konabilir. Tedavi, etiyolojik faktör temelinde çoğu kez cerrahi olup uzun dönem sonuçlar yüz güldürücüdür.

ANAHTAR SÖZCÜKLER: Anterior tarsal tünel sendromu, Sinir tuzaklanması, Talus

\section{INTRODUCTION}

The anterior tarsal tunnel (ATT) is formed by the fascia lining the inferior extensor retinaculum and talus as well as the navicular bone. The deep peroneal nerve (DPN) and its branches cross through this fibro-osseous canal by extending deep to the muscle tendons of the extensor hallucis longus $(E H L)$ and extensor digitorum longus (EDL) towards the distal direction (13).

This syndrome has first been described by Kopell and Thompson in 1963 (8). In 1968, Marinacci revealed the etiology and clinical signs of this syndrome more clearly and named it the "anterior tarsal tunnel syndrome" (ATTS) in order to differentiate it from medial tarsal tunnel syndrome. ATSS occurs more commonly among women (12). There are various reports focused on its anatomy, etiology, and management $(1,2,4,5,6,7,9)$.

We report an ATSS case resulting from a fibro-osseus structure that occurred after a missed talus fracture. 
relief alongside a burning pain in the right ankle in the last 2 months of this 6-month period. EMG examination was planned with a preliminary ATSS diagnosis. The EMG results were reported to be consistent with the ATTS signs. The patient was therefore operated on by our department on May, 2008. The deep peroneal nerve was exposed proximally and the extensor retinaculum was freed. A fibro-osseous structure was observed beneath the right deep peroneal nerve while tracking the nerve caudally, and the nerve was freed from this structure (Figure 4A-D). The pathology and

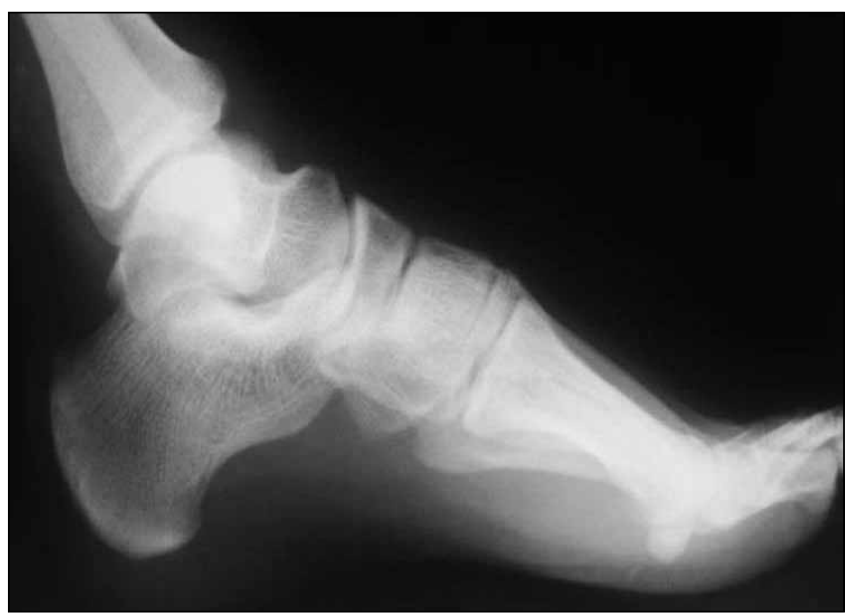

Figure 1: Lateral ankle radiography of the case. relationship between DPN and the other tissues of our case are illustrated in Figure 5 (Figure 5A,B). All the complaints of our case resolved in the early postoperative period and he exhibited no complaints within the 1-year follow-up period.

\section{DISCUSSION}

Anatomical and radiological studies on DPN anatomy are present $(2,6)$. DPN splits from the common peroneal nerve at the point where it extends beneath the peroneus longus muscle, just below the knee level, and descends with the anterior tibial artery in the anterior compartment of the leg. During that course, it is located lateral to the tibialis anterior muscle and medial to the extensor digitorum longus and extensor hallucis longus muscles (12). Then, just proximal to the medial malleolus, it heads towards the $Y$-shaped extensor retinaculum, and first passes beneath the superior extensor retinaculum followed by an extension beneath the inferior extensor retinaculum. Entrapment in ATTS generally takes place at the level of the inferior leg of the retinaculum. In our case, the initial EMG examination indicated the distal aspect of the extensor retinaculum.

Many ATTS cases with various etiologies have been reported since the first description $(1,10)$. The differential diagnosis of ATTS is summarized in Table I (Table I). In our case, the presence of a fibro-osseous structure that developed secondary to trauma although not directly associated with the fracture (distant to the fracture line), located caudal to the

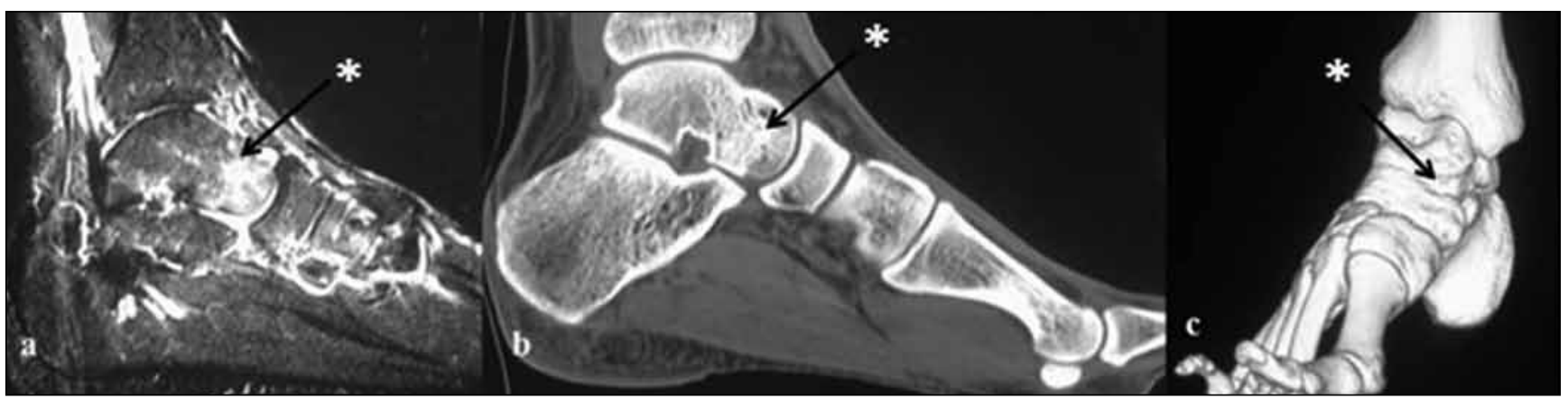

Figure 2: A) Sagittal T2 MR image of the patient showing edema in the talus and navicular bone, while sagittal CT B) and 3D CT C) are demonstrating a fracture line in the talus.

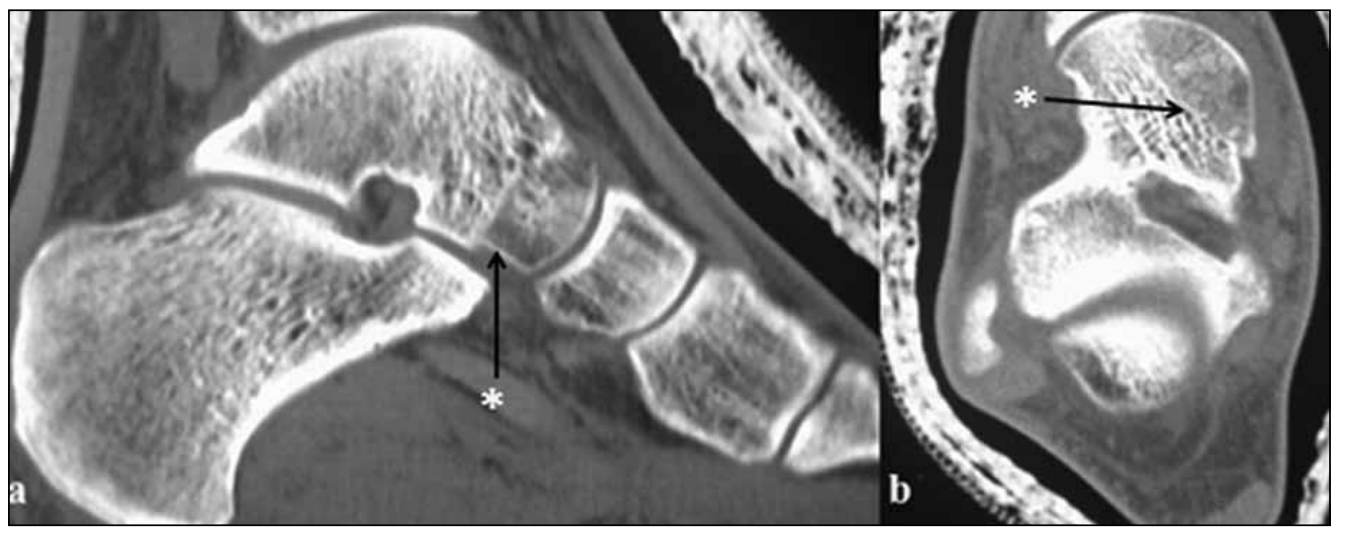

Figure 3: Sagittal A) and axial B) control CT (CT) of the case were evaluated to exhibit a fusion in the fracture line. 


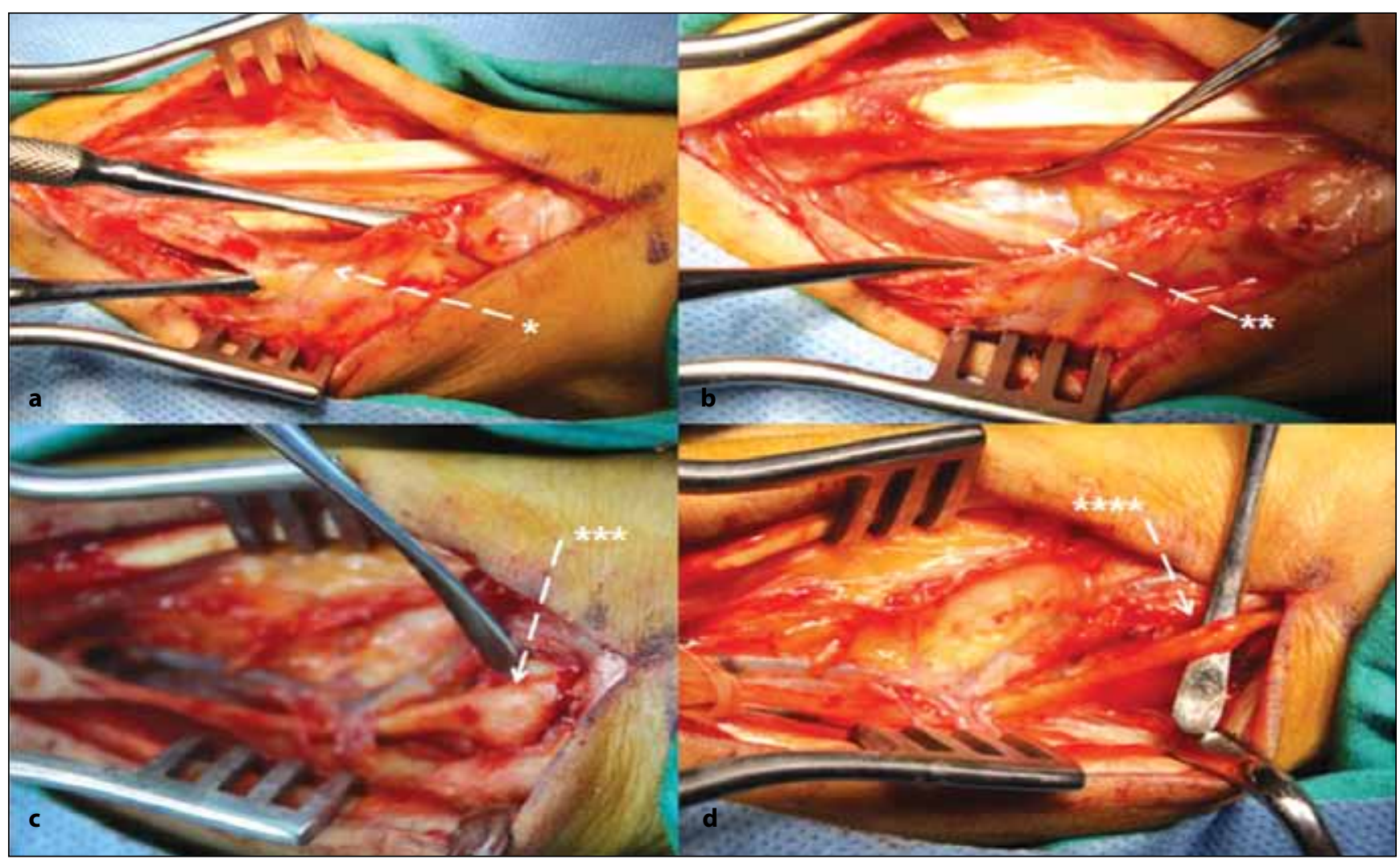

Figure 4: Perioperative images of the case concerning the: A) Extensor retinaculum $\left({ }^{*}\right)$, B) Deep peroneal nerve $\left({ }^{* *}\right)$, C) Fibro-osseous scar $(* * *), D)$ freeing of the nerve from the scar tissue $(* * *)$.

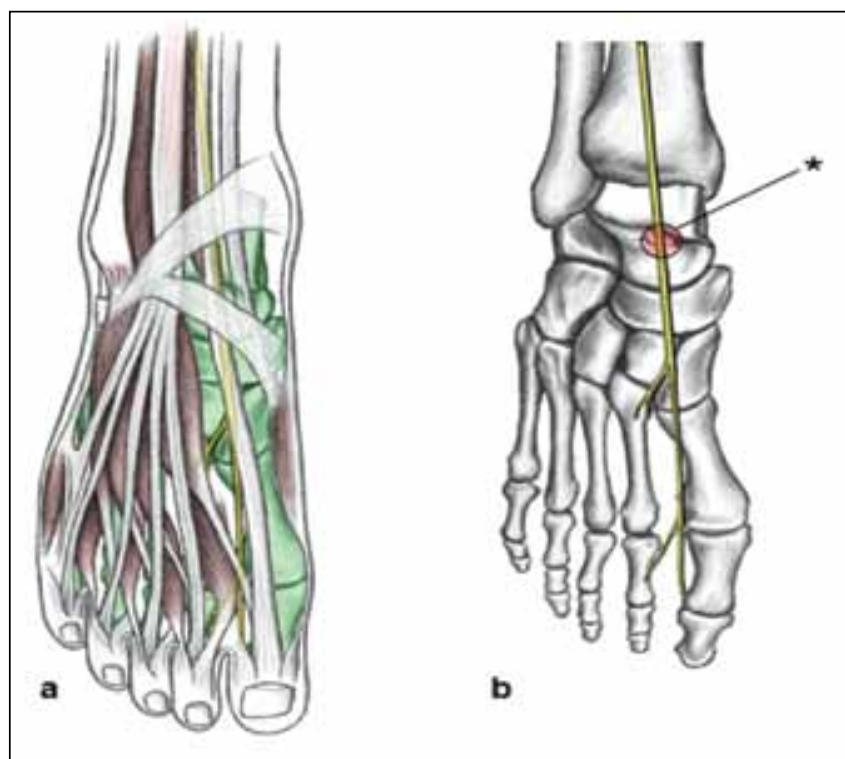

Figure 5: Illustrations for extensor retinaculum, deep peroneal nerve, muscles and tendons $\mathbf{A}$ ) and relationship between fibroosseous scar and deep peroneal nerve $\mathbf{B}$ ).
Table I: Differential Diagnosis of ATSS

- Causes of damage:

Osteophytes

Synovial pseudocyst

Tendon sheath or retinaculum ganglions

Neuroma

Abnormal/hypertrophic muscle

Fracture

Dorsalis pedis artery aneurysm

- Recurring compression (eg. Pinching shoes)

- Recurring strain (eg. Wearing a shoe with a high heel)

- Trauma in plantar flexion and/or inversion to the ankle

extensor retinaculum and just beneath the DPS, was observed intraoperatively. This fibro-osseous structure compressing the DPS was exposed with microdissection and freed from the nerve.

A sense of tightness in the ankle and dorsal foot during the onset of ATTS is a typical symptom (10). It is then followed by pain and paresthesia in the same area, while numbness occurs particularly in the first dorsal web space $(10,12)$. Although the pain increases with walking, it may also show up during 
rest, even to the degree of waking the patient in the middle of the night (12). Moving/shaking the foot may resolve the pain in some instances. Patients sometimes keep their foot at dorsoflexion for pain relief $(2,12)$. This is a typical symptom of ATTS. The tunnel sign can be commonly found in the compression area (11). Weakness and atrophy in the extensor digitorum brevis muscle may occur alongside hyperesthesia in the first dorsal web space as a result of the compression of the motor branch (10). However, most patients do not notice this weakness. Atrophy in the dorsolateral aspect of the forefoot can be easily detected during the examination. Clinically, paresthesia may be shown by passive plantar flexion of the foot or dorsal flexion of the thumb (11). The differential diagnosis for the drop foot profile is outlined in Table II (Table II).

The best diagnostic plan is a supportive combination of medical history and clinical examination findings with radiological and electrophysiological tests. Electrophysiological tests detect denervation potentials in the extensor digitorum brevis (EDB) muscle in advanced cases. The deep peroneal nerve exhibits delayed distal latencies (12). Absence of normal distal latencies in the deep peroneal nerve proximal to the ankle level and lack of denervation potentials in the tibialis anterior, extensor digitorum longus, extensor hallucis longus muscles innervated by that nerve eliminate $L 5$ radiculopathy and common peroneal neuropathy in the differential diagnosis. Additionally, most normal cases demonstrate fibrillation in the extensor digitorum brevis muscle but this finding is generally interpreted as a sign of local trauma. It may therefore usually go unnoticed or be neglected. When the changes regarding the denervation of the EDB muscle are associated with the symptoms of the anterior tarsal tunnel syndrome, the diagnosis is confirmed by electrodiagnostic tests. In our case, the clinical signs of ATTS were consistent with the electrophysiological test results.

Treatment varies depending on the etiology. Using special prostheses for shoes for prevention of excessive pronation or plantar flexion, avoiding tight shoes and high heels, physiotherapy, and local steroid injection can be mentioned among the conservative treatment options (3). Surgery is performed if these treatments fail to generate a response. Our patient presented at our department due to the persistence of his symptoms despite conservative treatment and the follow-up provided by the Orthopedics department. The early postoperative complaints of our case resolved completely and he currently has no complaints within his ongoing 1-year follow-up period.

\section{CONCLUSION}

The ATTS diagnosis can be made with a comprehensive clinical and neurological examination, and electrophysiological study. Treatment is based on the underlying etiology, while surgery is the most common treatment providing successful outcomes in the long term.

Table II: Differential Diagnosis of Drop Foot

\begin{tabular}{|c|c|c|c|c|c|c|}
\hline \multirow[b]{2}{*}{ Lesion } & \multirow[b]{2}{*}{$\begin{array}{l}\text { Localization } \\
\text { of changes in } \\
\text { senses }\end{array}$} & \multicolumn{5}{|c|}{ Motor Deficit } \\
\hline & & $\begin{array}{c}\text { Flexion } \\
\text { associated } \\
\text { with } \\
\text { gastrocnemius } \\
\text { (plantar } \\
\text { flexion) }\end{array}$ & $\begin{array}{l}\text { Biceps femoris } \\
\text { (knee flexion) }\end{array}$ & $\begin{array}{l}\text { Tibialis } \\
\text { posterior } \\
\text { (inversion in } \\
\text { the foot) }\end{array}$ & $\begin{array}{l}\text { Peroneus } \\
\text { longus / brevis } \\
\text { (Eversion in } \\
\text { the foot) }\end{array}$ & $\begin{array}{c}\text { Tibialis } \\
\text { anterior (foot } \\
\text { dorsal flexion) }\end{array}$ \\
\hline $\begin{array}{l}\text { Sciatic nerve } \\
\text { body }\end{array}$ & $\begin{array}{c}\text { Distal lateral leg } \\
\text { and beginning } \\
\text { of the foot }\end{array}$ & $x$ & $x$ & $x$ & $x$ & $X$ \\
\hline $\begin{array}{c}\text { Peroneal } \\
\text { branch of the } \\
\text { sciatic nerves }\end{array}$ & $\begin{array}{c}\text { As in common } \\
\text { peroneal }\end{array}$ & & $x$ & $x$ & $x$ & $x$ \\
\hline $\begin{array}{l}\text { L4 or L5 } \\
\text { Radiculopathy }\end{array}$ & Dermatomal & & & $x$ & $x$ & $x$ \\
\hline $\begin{array}{c}\text { Common } \\
\text { peroneal nerve }\end{array}$ & $\begin{array}{c}\text { The entire } \\
\text { upper portion }\end{array}$ & & & & $x$ & $x$ \\
\hline $\begin{array}{c}\text { Superficial } \\
\text { peroneal nerve }\end{array}$ & $\begin{array}{l}\text { Distal lateral } \\
\text { leg and dorsum } \\
\text { of the foot }\end{array}$ & & & & $x$ & $x$ \\
\hline $\begin{array}{c}\text { Deep peroneal } \\
\text { nerve }\end{array}$ & İnterdigital web & & & & & $x$ \\
\hline
\end{tabular}




\section{REFERENCES}

1. Akyüz G, Us O, Türan B, Kayhan O, Canbulat N, Yilmaz IT: Anterior tarsal tunnel syndrome. Electromyogr Clin Neurophysiol 40(2):123-128, 2000

2. Bracilovic A, Nihal A, Houston VL, Beattie AC, Rosenberg ZS, Trepman E: Effect of foot and ankle position on tarsal tunnel compartment volume. Foot Ankle Int 27(6):431-437, 2006

3. Dellon AL: Deep peroneal entrapment on the dorsum of foot. Foot Ankle 11:73-80, 1990

4. DiDomenico LA, Masternick EB: Anterior tarsal tunnel syndrome. Clin Podiatr Med Surg 23(3):611-620, 2006

5. Huang KC, Chen YJ, Hsu RW: Anterior tarsal tunnel syndrome: Case report. Changgeng Yi Xue Za Zhi 22(3):503-507, 1999

6. Ikiz ZAA, Ucerler $\mathrm{H}$, Uygur M: Dimensions of the anterior tarsal tunnel and features of the deep peroneal nerve in relation to clinical application. Surg Radiol Anat 29:527-530, 2007

7. Kennedy JG, Baxter DE: Nerve disorders in dancers. Clin Sports Med 27(2):329-334, 2008
8. Kopell HP, Thompson WAL: Peripheral entrapment neuropathies. Baltimore: Williams \& Wilkins, 1963: 35-37

9. Krishnan KG, Pinzer T, Schackert G: A novel endoscopic technique in treating single nerve entrapment syndromes with special attention to ulnar nerve transposition and tarsal tunnel release: Clinical application. Neurosurgery 59:89-100, 2006

10. Lee CC, Tindal SC, Kliot M: Entrapment syndromes of peripheral nevre injuries. In:Winn HR, editor. Youmans Neurological Surgery. Vol 4, 5th ed. 2004:3921-3939

11. Lollis SS, Nikas DC: Entrapment neuropathies the lower extremities. In: Schmidek HH, Roberts DW. Operative Neurosurgical Techniques. Vol 2, 5th Ed. Philadelphia, PA. 2006: 2311-2317

12. McGillicuddy JE, Sullivan SE: Entrapment/Compression Neuropathies. In: Batjer HH, Loftus CM. Textbook of Neurological Surgery Principles and Practice Vol 3, 1st ed. 2003:2201-2228

13. Zongzhao L, Jiansheng Z, Li Z: Anterior tarsal tunnel syndrome. J Bone Joint Surg 73B(3):470-473, 1991 